\title{
A CASE REPORT OF JUVENILE FORM OF METACHROMATIC LEUKODYSTROPHY
}

\author{
Muhammad Mohsin Sajjad, Sidra Yousaf* \\ Royal College of Physicians Ireland, *College of Physicians \& Surgeons, Karachi Pakistan
}

\begin{abstract}
Metachromatic Leukodystrophy is a lysosomal storage autosomal recessive disease characterized by arylsulphatase enzyme deficiency, with central and peripheral demyelination. We report a case of a 15-year-old girl with 6 months history of progressive muscular weakness, poor school performance, gradual memory loss and gait disturbance. Neurological examination was grossly normal, except mild muscle wastage in both upper and lower limbs and slight reduction of power globally in all limbs. Routine bloods including a lumbar puncture was normal and the diagnosis of metachromatic leukodystrophy was made on the findings of magnetic resonance imaging (MRI) brain.
\end{abstract}

Keywords: Arylsulphatase, Demyelination, Leukodystrophy.

How to Cite This Article: Sajjad MM, Yousaf S. A Case Report of Juvenile form of Metachromatic Leukodystrophy. Pak Armed Forces Med J 2021; 71(6): 2255-2256. Doi: $\quad$ Dttps://doi.org/10.51253/pafmj.v71i6.4362

This is an Open Access article distributed under the terms of the Creative Commons Attribution License (https://creativecommons.org/licenses/by-nc/4.0/), which permits unrestricted use, distribution, and reproduction in any medium, provided the original work is properly cited.

\section{INTRODUCTION}

Metachromatic Leukodystrophy (MLD) is caused due to arylsulfatase enzyme deficiency and is a lysosomal storage disorder. Genetically it is an autosomal recessive variant. ${ }^{1}$ This disease has three types, depending on age of onset, infantile, juvenile and adult type. The mean age of survival is 5 years. ${ }^{2}$ Diagnosis includes deficient activity of arylsulfatase A (ARSA) in the white blood cells and detection of sulfatides in the patient's urine. $^{3}$

\section{CASE REPORT}

A 15-year-old girl presented to Khyber Teaching Hospital Peshawar with 6 months' history of progressive muscular weakness, poor school performance, gradual memory loss and gait disturbance. The patient had no significant history of muscle weakness. General physical examination was unremarkable with temperature: $99^{\circ} \mathrm{F}$, pulse: $78 / \mathrm{min} \mathrm{BP}: 110 / 70 \mathrm{mmHg}$. CNS examination showed: GCS 15/15, cranial nerves were intact. Sensory system showed normal touch, pain and vibration senses. Motor system showed mild muscle wastage and atrophy bilaterally, normal tone, power $(4 / 5)$ reflexes in both upper and lower limbs. Based on history and clinical examination our differential diagnoses were multiple sclerosis, subacute combined degeneration of spinal card, tuberculosis meningitis, muscular dystrophy. Investigations showed normal blood count, LFT's, RFT's, urine R/E, serum electrolytes and negative viral profile. ESR was $30 \mathrm{~mm} / 1$ st hour, CPK

Correspondence: Dr Muhammad Mohsin Sajjad, Royal College of Physicians Ireland

Received: 29 May 2020; revision received: 28 Sep 2020; accepted: 10 Oct 2020 was $19 \mathrm{mg} / \mathrm{dl}$, LDH was $640 \mathrm{mg} / \mathrm{dl}$, CRP was $23 \mathrm{mg} / \mathrm{d}$. Repeated blood culture \& urine culture were negative. Montoux test was also negative. Chest $x$-ray was normal. CSF R/E was normal. Oligoclonal bands were not detected in CSF \& blood plasma. MRI brain showed bilateral symmetrical high intensity signal in cerebral white matter (Figure A \& B). Focal T2 and flair high intensity signal were seen in bilateral thalami, brain stem and middle cerebellar peduncle. ARSA-A enzyme activity was decreased in the blood and sulfatide was found in urine. These tests confirmed the diagnosis of MLD.

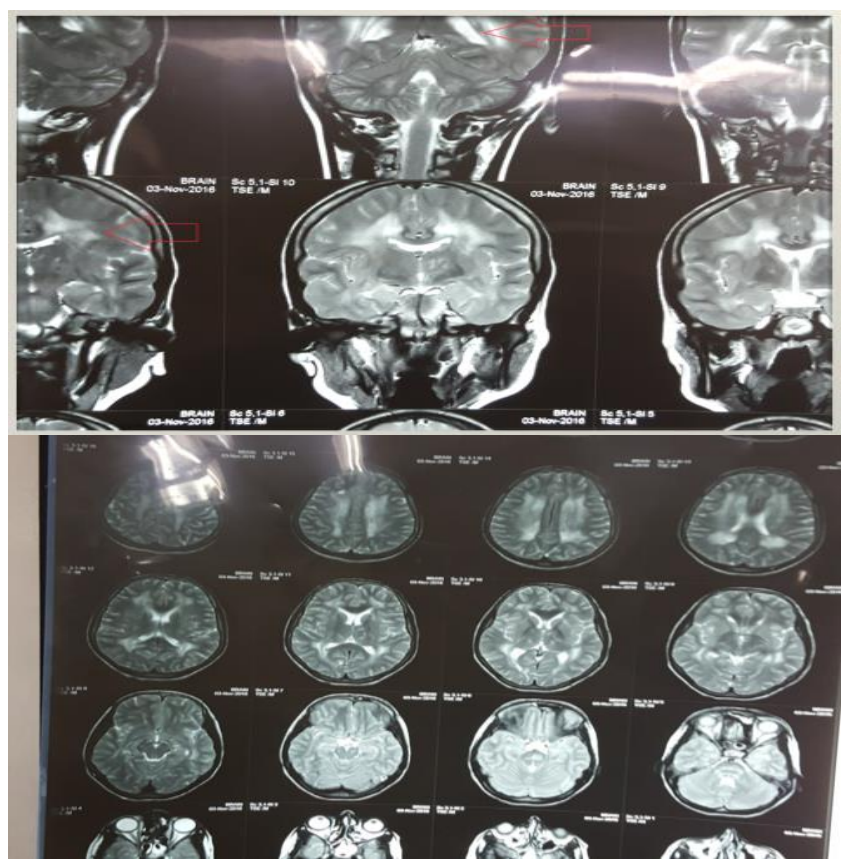

Figure (A\&B): MRI Brain with bilateral symmetrial periventricular deep white matter signal changes. 


\section{DISCUSION}

MLD is characterized by rapid cognitive and neurological manifestations. Pain is a serious problem in advanced cases which is neurological in origin. As already mentioned, this disease occurs due to the deficiency of ARSA enzyme and is an autosomal recessive lysosomal storage disorder (LSD). ${ }^{4}$ Our patient was also having severe neurological pain.

Signs and symptoms vary according to age of presentation. The main symptoms in patients with late infantile type mainly involves gait problem initially, this is followed by loss of movements, language difficulties and loss of head control. Finally, the patient becomes bed ridden.5,6 Our patient also had some of the features of juvenile type of MLD.

Allogeneic hematopoietic stem cell transplantation for MLD is the only option of treating this debilitating disease but survival rate still depends on various conditions. A cohort study highlighting survival and improvement of patients after stem cell transplantation after 5 years of transplantation was found to be $59 \%$. Survival and symptoms improved more in HLA matched siblings. ${ }^{7}$

Certain inflammatory markers are raised in MLD. Anti-inflammatory drugs like simvastatin is another treatment option to improve CNS function. A study on mice model showed improvement of swimming performance and gait in mice. ${ }^{8}$ However, our patient did not receive such therapy and was mainly treated symptomatically.

Unrelated umbilical cord blood transplant for juvenile MLD is also an effective therapy. A study in USA was done on three siblings having juvenile type of the disease who were treated with umbilical cord blood transplant. Follow-up showed that symptoms of the oldest child worsened while the younger child gained more benefits in the form of symptom improvement. Therefore, individual genetic variability is important before administering this therapy. ${ }^{9}$ Another study highlighted the importance of gene therapy by admin- istering adeno-associated virus (AAV) is very beneficial in improvement of signs and symptoms in MLD. ${ }^{10}$ In short MLD is a fatal disease and suspected families must be screened for ARSA enzyme in urine.

\section{Conflict of Interest: None.}

\section{Authors' Contribution}

MMS: Conception and design, SY: Data acquisition and final script writing.

\section{REFERENCES}

1. Han M, Jun SH, Lee YJ, Eun BL, Lee SJ, Seong MW, et al. Bio-chemical and genetic analysis of seven Korean individuals with suspected metachromatic leukodystrophy. Ann Lab Med 2015; 35(4): 458-462.

2. Mahmood A, Berry J, Wenger DA, Escolar M, Sobeih M, Raymond G, et al. Metachromatic leukodystrophy: a case of triplets with the late infantile variant and a systematic review of the literature. J Child Neurol 2010; 25(5): 572-580.

3. Therrell BL, Padilla CD, Loeber JG, Kneisser I, Saadallah A, Borrajo GJ, et al. Current status of newborn screening worldwide: 2015. Semin Perinatol 2015; 39(3): 171-187.

4. Verstegen RH, Theodore M, van de Klerk H, Morava E. Lymphatic edema in congenital disorders of glycosylation. JIMD Rep 2012; 4(1): 113-116.

5. Liaw HR, Lee HF, Chi CS, Tsai CR. Late infantile metachromatic leukodystrophy: Clinical manifestations of five Taiwanese patients and Genetic features in Asia. Orphanet J Rare Dis 2015; 10(1): 144 .

6. Zlotogora J, Bach G, Barak Y, Elian E. Metachromatic leukodystrophy in the habbanite Jews: high frequency in a genetic isolate and screening for heterozygotes. Am J Hum Genet 1980; 32(5): 663-669.

7. Boucher AA, Miller W, Shanley R, Ziegler R, Lund T, Raymond $\mathrm{G}$, et al. Long-term outcomes after allogeneic hematopoietic stem cell transplantation for metachromatic leukodystrophy: the largest single-institution cohort report. Orphanet J Rare Dis 2015; 10(2): 94.

8. Stein A, Stroobants S, Gieselmann V, D'Hooge R, Matzner U. Anti-inflammatory therapy with simvastatin improves neuroinflammation and CNS function in a mouse model of metachromatic leukodystrophy. Mol Ther 2015; 23(7): 1160-1168.

9. Rosenberg JB, Kaminsky SM, Aubourg P, Crystal RG, Sondhi D. Gene therapy for metachromatic leukodystrophy. J Neurosci Res 2016; 94(11): 1169-1179.

10. Rosenberg JB, Kaplitt MG, De BP, Chen A, Flagiello T, Salami C, et al. 10-Mediated APOE2 central nervous system gene therapy for APOE4-associated alzheimer's disease. Hum Gen Ther Clin Develop 2018; 29(1): 24-47. 